\title{
THE EFFECT OF THE CONTACT SURFACE SHAPE ON THE BEARING CAPACITY OF STRIP FOOTING ON SAND
}

\author{
Abd El Megeed kabasy Mohamed \\ Civil Engineering Department, Assiut University, Assiut, Egypt
}

(Received December 26, 2007 Accepted January 13, 2008)

\begin{abstract}
Bearing capacity of the strip footing on sand, is well known by Terzaghi and anothers. Many investigators are implemented in improvement of the bearing capacity of the strip footing resting on sand by using skirts on the sides of the footing to improve the bearing capacity and to elongate the contact surface of the footing with soil. Another studies, have used a reinforcement material such as geotextile or geogrid to reinforce the sand layers. In this present experimental study, it is intended to observe the behavior of the strip footing on sand with different footing section shapes. A series of tests with different foundation section shapes, are carried out to study the effect of the section shape of the foundation on bearing capacity. The results showed that the most reliable bearing capacity is that under a rectangular strip footing section shape.
\end{abstract}

\section{INTRODUCTION}

The ultimate bearing capacity of a particular soil, under a shallow footing, was investigated theoretically by [6] using the concept of plastic equilibrium as early as in 1921.Foundation resting on sand has been widely employed and the relevant theory for the calculation of ultimate bearing capacity is available since the proposal of Terzaghi [8]. Meyerhof [5], Hansen[3], Vesic [9] and others, modified the equation suggested by Terzaghi by the addition of several correction factors as depth, shape and inclination factors.

It is evident from the general shear failure mechanism involved in the development of bearing capacity theory that the bearing capacity of a foundation resting on a homogeneous layer of sand increases with the increase in the total length of the failure surface which mobilizes higher shear resistance [1].

Increase in length of the failure surface can be produced by increasing the width of the foundation or increasing the depth of the foundation using skirts [1]. The structural skirts fixed to the edges of shallow foundations to increase the length of failure surface that would develop under central vertical loading condition and therefore improve the bearing capacity of the foundations resting on sand Fig. (1).

The objective of this present research is investigating the effect of increasing the length of failure through increasing the contact surface between the footing and the soil in curved direction towards the soil. 


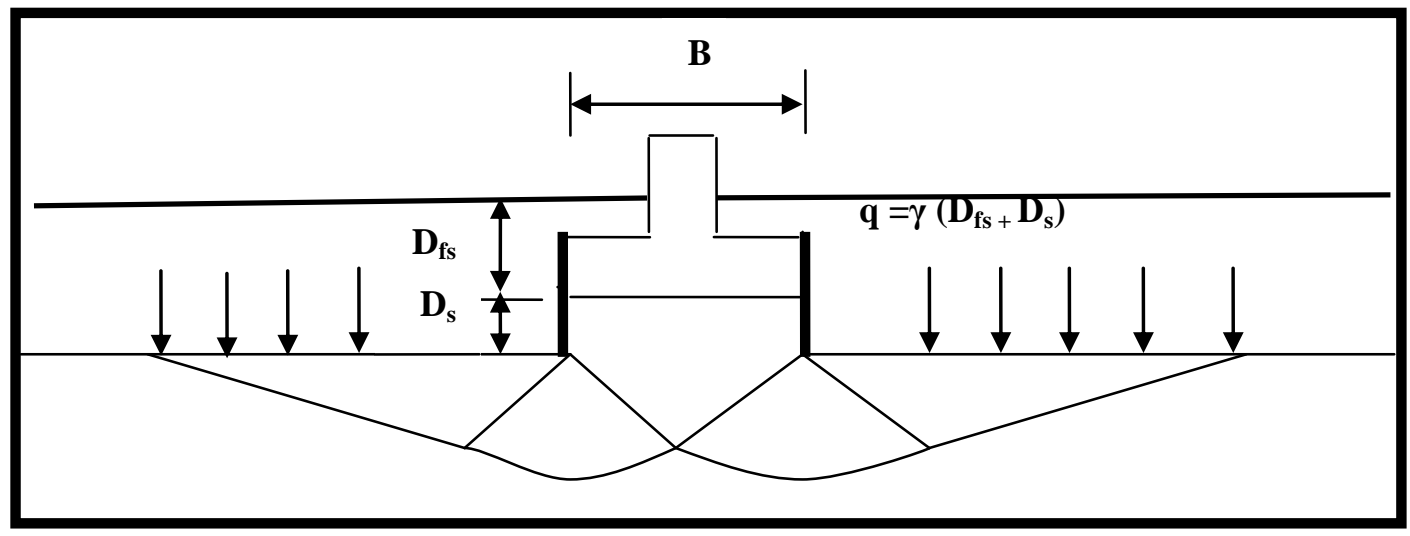

Fig (1) Bearing failure mechanism using Skirts

\subsection{REVIEW OF BEARING CAPACITY EQUATIONS}

Terzaghi [3] proposed an equation for calculating the ultimate bearing capacity of shallow strip foundation bearing on a homogeneous layer of sand and subjected to central vertical loading as shown in Figure (2). This has the following form:

$\mathrm{q}_{u l t}=\gamma \mathrm{D}_{\mathrm{f}} \mathrm{Nq}+0.5 \gamma \mathrm{BN}_{\gamma}$

where

$\mathrm{q}_{u l t} \quad=$ ultimate bearing capacity

$\gamma \quad=$ unit weight of the soil

$\mathrm{D}_{\mathrm{f}} \quad$ =foundation depth

$\mathrm{B} \quad$ =foundation width

$\mathrm{N}_{\mathbf{q}}$ and $\mathrm{N}_{\gamma}$ are bearing capacity factors

Values for $\mathrm{N}_{\mathrm{q}}$ and $\mathrm{N}_{\gamma}$ are given by Terzaghi [8] in terms of the peak angle of internal friction $(\varphi)$. Following this, many other researchers have proposed different forms for the bearing capacity factors, based on different assumptions [5].

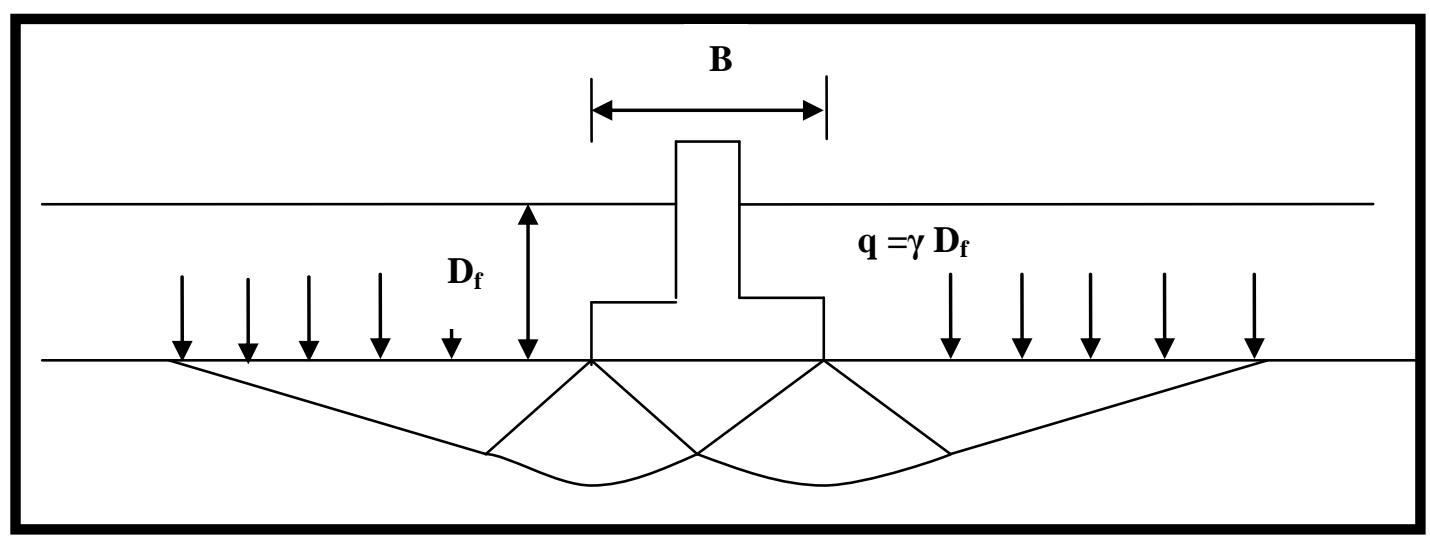

Fig (2) Bearing Capacity Failure Mechanism 
Bearing capacity failure mechanism in soil under a rough rigid continuous foundation subjected to vertical central load proposed by Terzaghi [5] Hansen [3],Vesic [9] and others. These authors also proposed additional correction factors for shape, depth and load inclination. For shallow strip foundation with structural skirts resting on dense sand and subjected to central vertical load, figure 1, modifications to the general ultimate bearing capacity equation are required [1,2].

\subsection{SOURCES OF APPROXIMATIONS IN BEARING CAPACITY}

The approximations involved in the derivation and use of the ultimate bearing capacity, $\mathrm{q}_{u l t}$, given by Equation (1), may be summarized as follows[7]:

1. The soil mass is assumed to be purely homogeneous and isotropic, while the soil in nature is extremely heterogonous and anisotropic.

2. The shear strength of soil within a depth $\mathrm{D}$, from the surface is neglected.

3. There may be three types of failure modes;

(i) General shear failure.

(ii) Local shear failure.

(iii) Punching shear failure.

As shown in figure (2), the theoretical considerations behind Equation (1), correspond only to the general shear mode, which is typical for soils of low compressibility, such as dense sands and stiff clays. In the local shear failure, only a partial state of plastic quilibrium is developed with significant compression under the footing.In the punching shear mode, however, direct planar shear failures occur only along the vertical irections around the edges of the footing. Therefore, Equation (1) is no longer applicable for soils of high compressibility, such as loose sand and soft clay, which may undergo, either the local shear or the punching shear failures. Consequently, the results of Equation (1) will only be approximate for such soils. In reality, the excessive settlement and not the shear failure is normally the limiting criterion in high compressibility soils.

4. The ultimate bearing capacity calculations are very sensitive to the values of shear strength parameters $\mathrm{c}$, and $\varphi$, which are determined in the laboratory using 'undisturbed' soil samples, which may not necessarily represent the true conditions prevailing at the site.

5. A factor of safety of 2 to 3 is used normally, in order to obtain the allowable bearing capacity, $\mathbf{q}_{\mathbf{a}}$, which contains a significant amount of reserve strength in it. Accounting for all the inaccuracies and approximations cited herein. This significantly large factor of safety represents the degree of uncertainties and our 'ignorance' in determining the real soil conditions.

\section{EXPERIMENTAL WORK}

\subsection{TEST SETUP PROCEDURES}

The original strip footing (O) was $50 \mathrm{~mm}$ wide and $40 \mathrm{~mm}$ depth and $250 \mathrm{~mm}$ long. The another strip footing A,B,C and D were the same as the Original strip footing (O), but with $20 \mathrm{~mm}$ straight depth, and the rest of depth is curved. All the strip footing are manufactured from rigid beech timber. All tests were carried out on the surface of the 
homogeneous sand. The height of sand in the tank was $650 \mathrm{~mm}$ placed in a rectangular steel tank with inside dimension of $1000 \mathrm{~mm}$ length $750 \mathrm{~mm}$ depth and $254 \mathrm{~mm}$ width. All sides of the tank were made from steel plates with thickness $3 \mathrm{~mm}$ except the front size which was made from prespex of $10 \mathrm{~mm}$ thickness to observe the behavior the sand loading process. Each side of the tank was braced with stiffeners to avoid lateral displacement during soil placement in the tank. The strip footing was placed on the sand and was centered such as the length of the footing is parallel to the shorter side of the tank. The original strip footing was driven $20 \mathrm{~mm}$ in the sand as a depth of footing. In the rest of the footing, only the curved section part was driven in the sand to observe its effect on the bearing capacity.

Foundation was placed centrally across the width of the tank. The central vertical loads were applied by positioning the tank under a test loading frame. The load on the strip footing was applied by manual screw jack. A load cell measures the applied load and a dial gauge to measure the displacement of the footing. The tank and its dimension are shown in Fig (3). The tank was then filled with sand using sand according to the relative density required. Compaction is controlled by adjusting the height of the sand layer and the weight of soil required for every layer. Each layer is compacted carefully by hand rod timber to achieve the density required. This compaction method was calibrated before, to have different variations of sand densities.

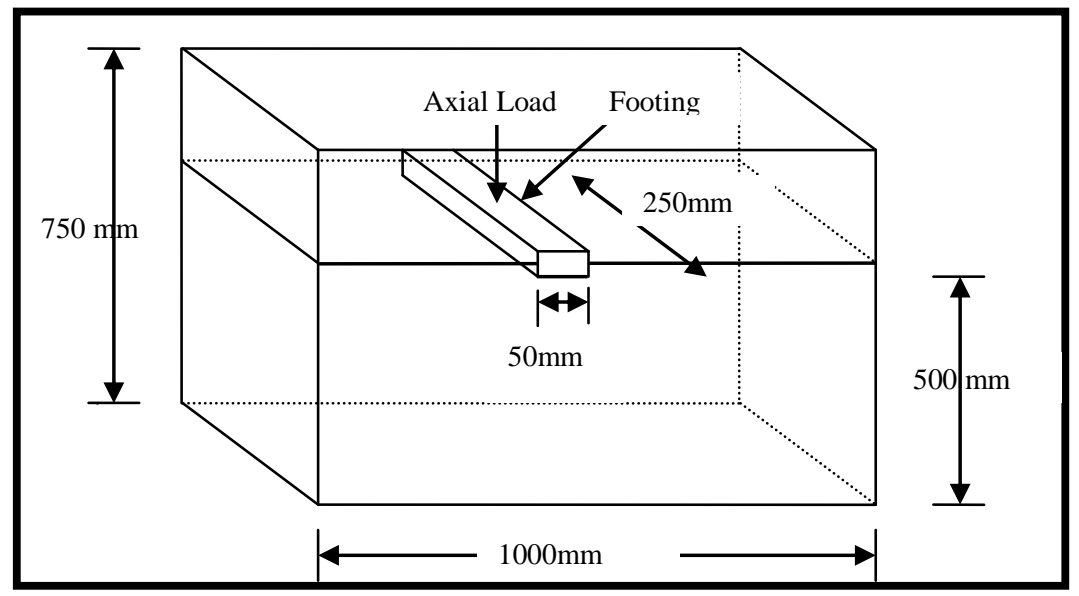

Fig ( 3 ) The Dimension of the tank used in the present study

\subsection{SOIL MATERIAL}

The sand used, was graded silica sand with a particle size range from 0.1 to $4.0 \mathrm{~mm}$ and a mean particle diameter of $0.82 \mathrm{~mm}$. The sand was placed in the tank and uniform dense state was achieved, (a relative density of 70 per cent). The peak angle of friction for the dense sand was determined. The properties of the sand used in the study are shown in Fig. (4) and Table (2). 


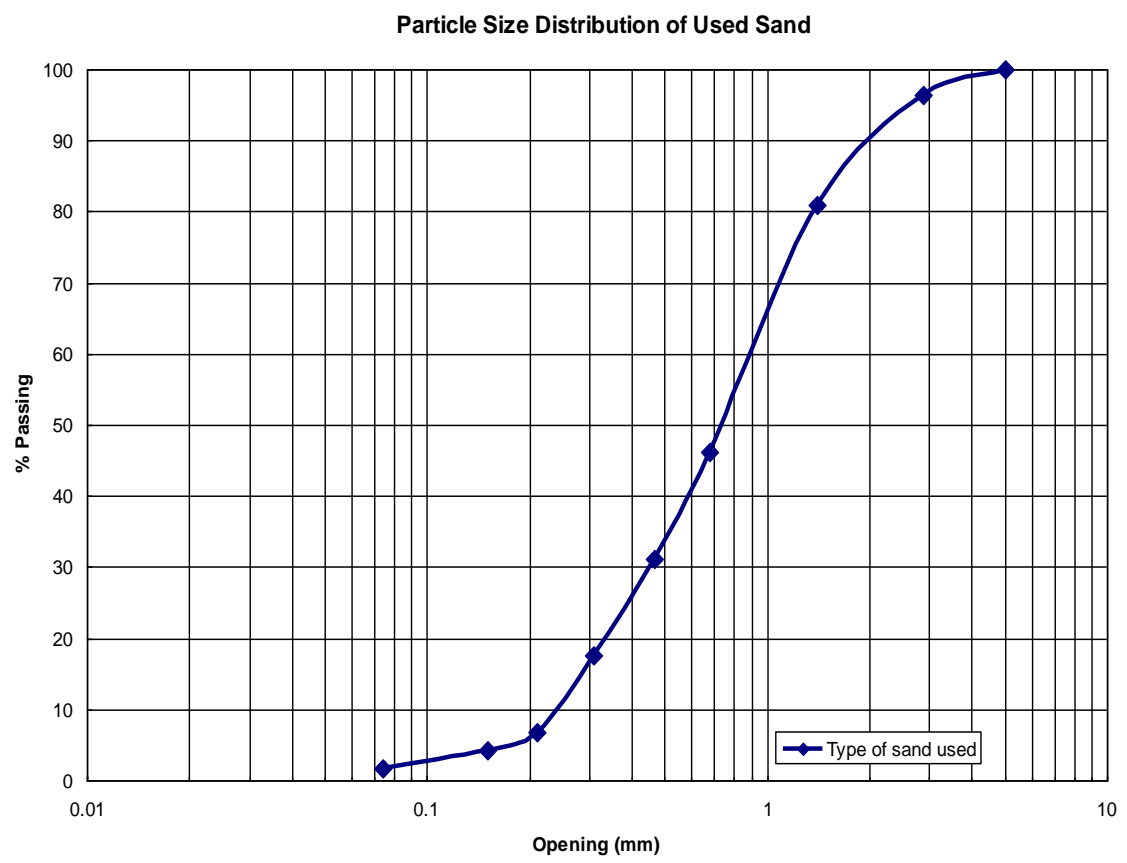

Fig ( 4 ) Particle size distribution of the used sand

Table (2) Mechanical properties of used sand

\begin{tabular}{|l|l|l|l|l|l||l||l|l|l|}
\hline Property & $\begin{array}{l}\mathrm{D}_{10} \\
\mathrm{~mm}\end{array}$ & $\begin{array}{l}\mathrm{D}_{30} \\
\mathrm{Mm}\end{array}$ & $\begin{array}{l}\mathrm{D}_{60} \\
\mathrm{~mm}\end{array}$ & $\mathrm{C}_{\mathrm{u}}$ & $\mathrm{C}_{\mathrm{c}}$ & $\begin{array}{l}\gamma_{\mathrm{dmax}} \\
\mathrm{t} / \mathrm{m}^{3}\end{array}$ & $\begin{array}{l}\gamma_{\mathrm{dmin}} \\
\mathrm{t} / \mathrm{m}^{3}\end{array}$ & $\mathrm{R}_{\mathrm{d}} \%$ & $\begin{array}{l}\Phi \\
\mathrm{deg} .\end{array}$ \\
\hline \hline Sand & 0.25 & 0.45 & 0.9 & 3.6 & 0.9 & 1.92 & 1.57 & 70 & 35 \\
\hline
\end{tabular}

\subsection{FOOTING TESTED}

Five rigid timber strip footing were prepared. One is normal strip rectangular section shape named Original (O). Another four tested footing were choosed with different curved section shape and these shapes. Each shape has its upper part rectangular and the rest of section was curved. The curved section footings and their properties, shapes, equations, curved lengths, and curved area, are shown in fig (5) and table (3). 


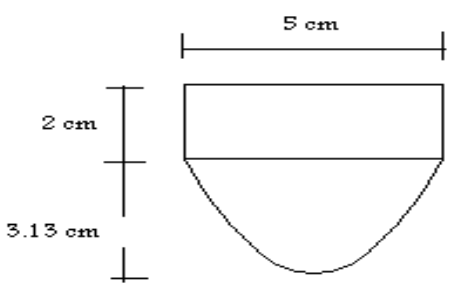

Footing A

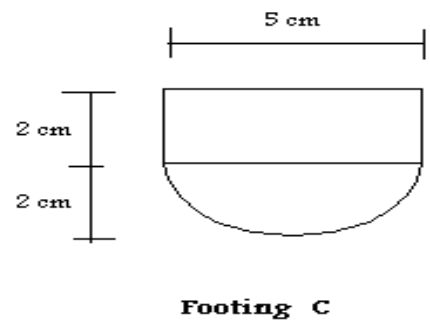

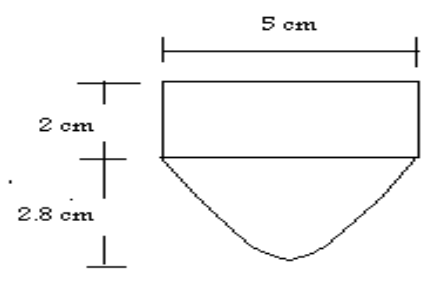

Footing D

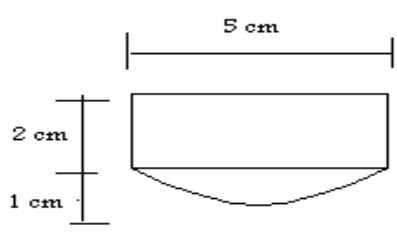

Footing B

Fig ( 5 ) The Sketch section of the curved footing

Table (3) Curved footing section properties

\begin{tabular}{|c|c|c|c|}
\hline Footing & $\begin{array}{l}\text { The formula of the curve beneath } \\
\text { footing }\end{array}$ & $\begin{array}{l}\text { The long of the } \\
\text { curved part }(\mathrm{cm})\end{array}$ & $\begin{array}{c}\text { The area of the curved } \\
\text { part }(\mathrm{cm} 2)\end{array}$ \\
\hline$\overline{\bar{A}}$ & $\mathrm{Y}^{2}=0.5 \mathrm{X}^{2}$ & 8.20 & \begin{tabular}{|c|}
9.62 \\
\end{tabular} \\
\hline B & $Y=\operatorname{Sin} X$ & 5.46 & 3.16 \\
\hline C & $Y^{2}=0.4\left(25-4 X^{2}\right)^{0.5}$ & 6.94 & 7.60 \\
\hline D & $Y^{2}=0.5 X^{3}$ & 7.48 & 8.00 \\
\hline
\end{tabular}

\section{RESULTS AND DISCUSSION}

\subsection{TESTS AND OBSERVATIONS}

- The load on each footing is applied till reaching failure.

- All the footing has $20 \mathrm{~mm}$ height above the sand bed.

- The same sand density is used for all footing tested.

- Each footing is tested three times and the average is determined.

- All the circumstances are the same for all tests.

- The load settlement curve for each footing is drawn. 


\subsection{ANALYSES}

From the analyses of the ultimate bearing capacity or ultimate load, it is obvious from the curves in Figs (6),(7), (8), that the maximum ultimate load occurs under the original strip footing with rectangular section shape. Referring to the curved footing section, the max bearing capacity occurs using footing B. The footing C, D and A have an descending order in the ultimate load, they have $97.8 \mathrm{~kg}, 81.5 \mathrm{~kg}$ and $69.2 \mathrm{~kg}$ respectively.

Making relation between the ultimate load and the area of the curved section (for the curved footing only), fig (9), it appears generally that, the ultimate load decrease with the increasing of the curved section area or the contact area.

Also observing the relation between the ultimate load and the length of the curved section, it appears that the ultimate load decrease with the increasing of the length of the curved section, or contact surface Fig (10). This conclusion does not represent a contrary to the conclusion of Al-Aghbari and another's [1] and [4], because they used another design to increase the contact surface between the footing and the soil base. They mentioned that, for increasing the bearing capacity of the strip footing, it is necessary to increase the contact surface of the strip footing with the soil so, they advice the using of skirts at the two sides of the strip footing and, they have been proved that the skirts can increase the bearing capacity of the strip footing [1].

In our present case, there are no skirts, but a strip footing was designed with its lower part curved towards the soil base, making an elongation of the contact surface. This curved section helped in accelerating the cone formation which is usually formed under the original strip footing. This is the main cause of the decreasing of the ultimate load as the contact surface increase in curving form of section towards the soil base.

Referring to the relation of the curved depth with the ultimate load Fig (11), it is obvious, that with increasing of depth of the curvature, the bearing or the ultimate load decrease. Also as the curve reach to be flat, the ultimate load increase (see the case of footing $\mathrm{C}$ and $\mathrm{B}$.

\section{CONCLUSIONS}

1. The rectangular section shape strip footing is the most accurate shape which gives the maximum ultimate load.

2. The curved section shapes of strip footing, do not give an advantage over the rectangular shape, but decrease the ultimate load according to its curvature.

3. As the curvature of the strip footing reaches to be zero, as the bearing increases.

4. With the increasing of curved depth in sand, a decreasing in bearing capacity will occur.

\section{ACKNOWLEDGMENTS}

The idea of this research reported in this paper was supported by Dr. Fathalla El Amin. The author would like to thank him for his help. 
Load-Settlement Curve For Footing (0)

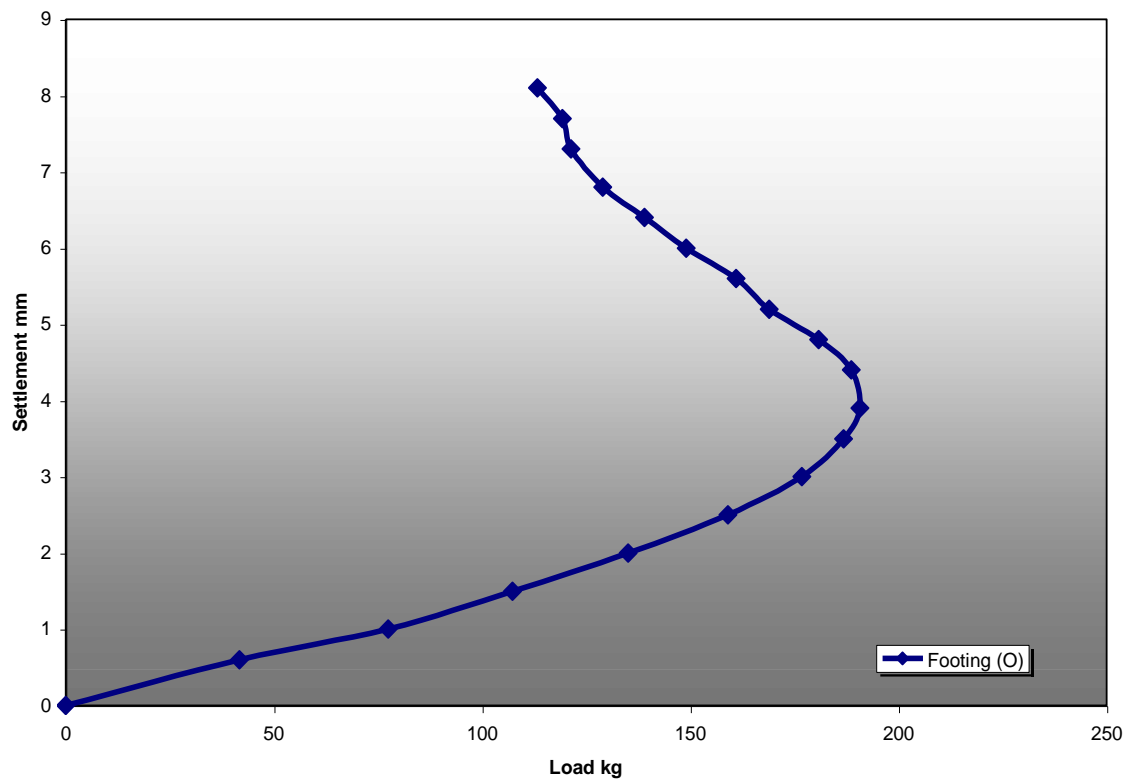

Load-Settlement Curve For Footing (A)

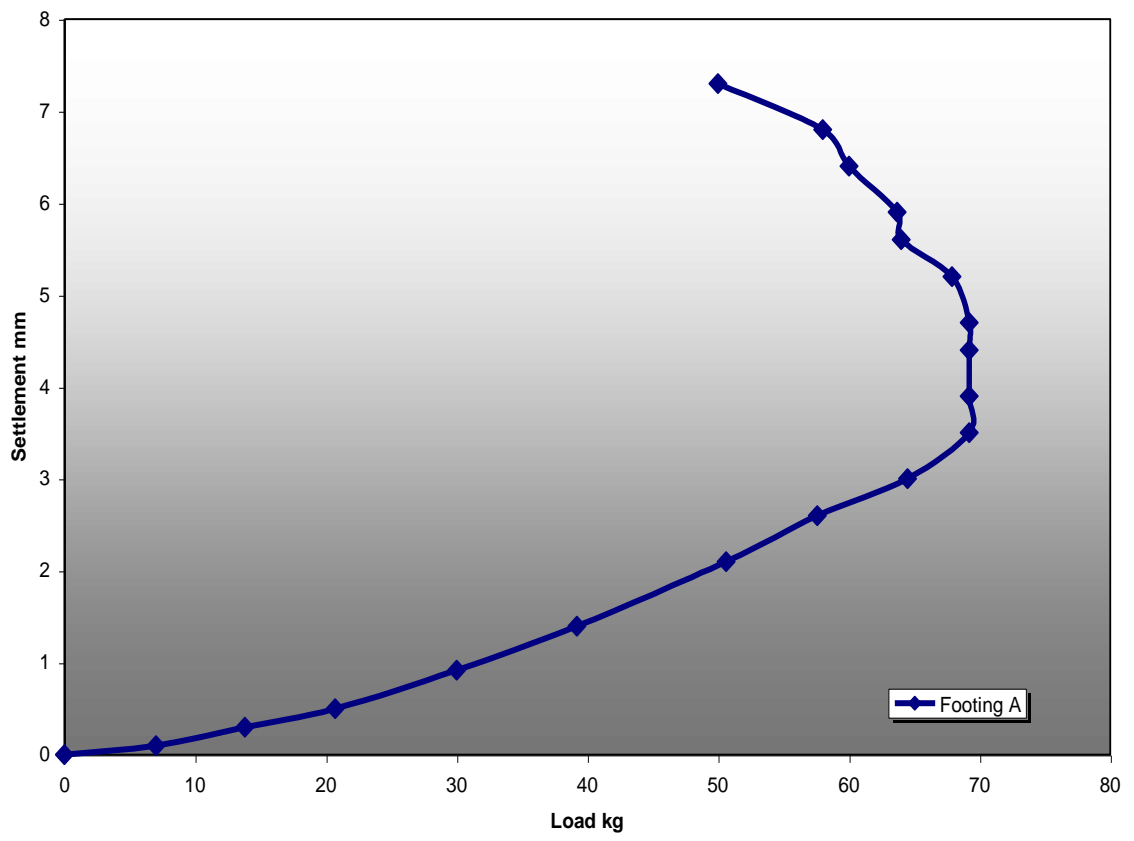

Fig ( 6 ) Footing $\mathrm{O}$ and $\mathrm{A}$ 
Load-Settlement Curve For Footing (B)

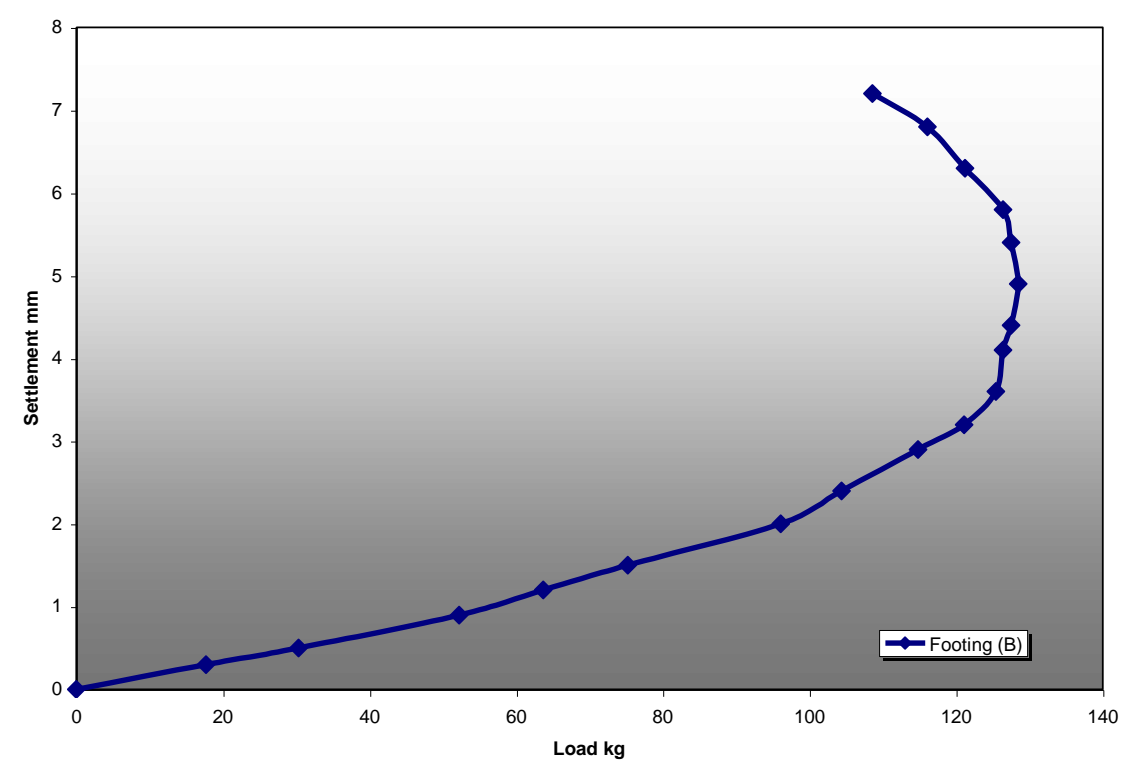

Load-Settlement Curve For Footing (C)

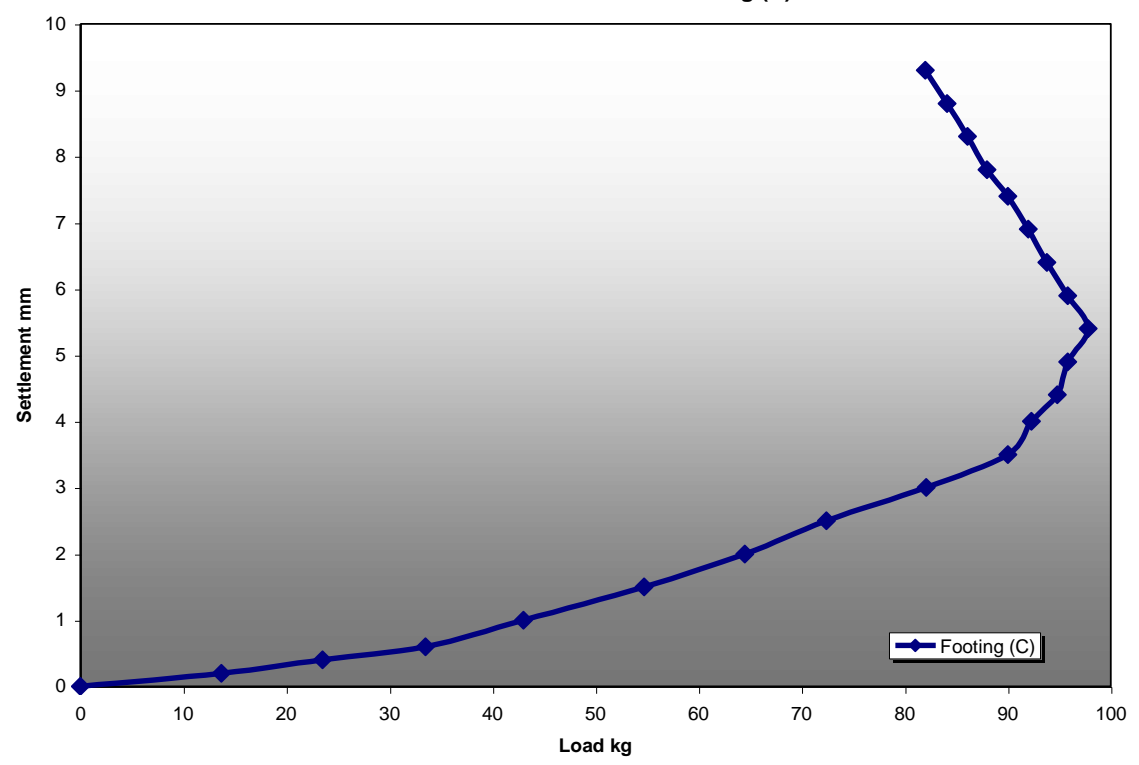

Fig ( 7 ) Footing B and C 

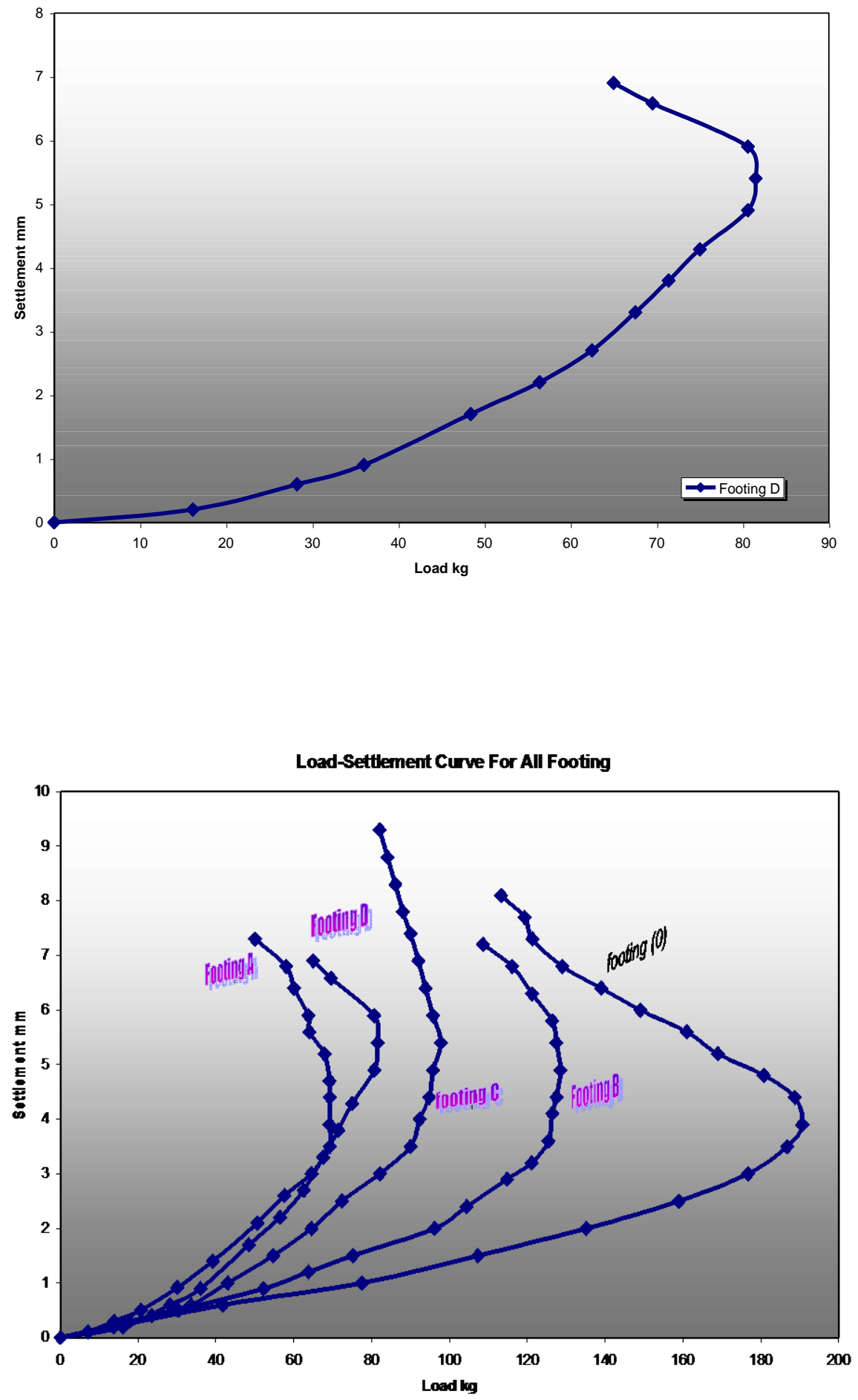

Fig (8) Footing $D$ and All footing 

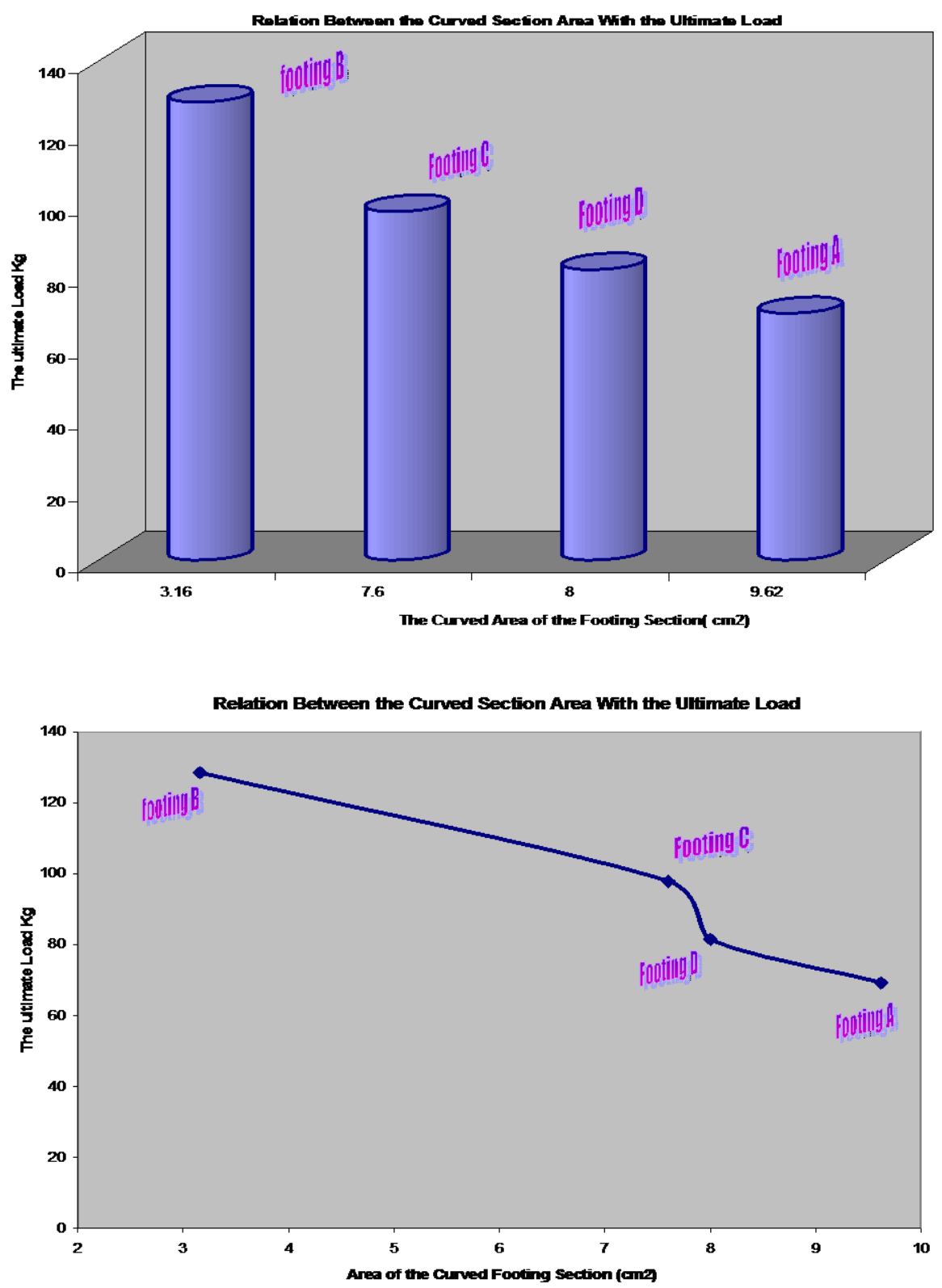

Fig ( 9 ) Section curved area with the ultimate load 
Relation Between the Section Curved Length With the Ultimate Load
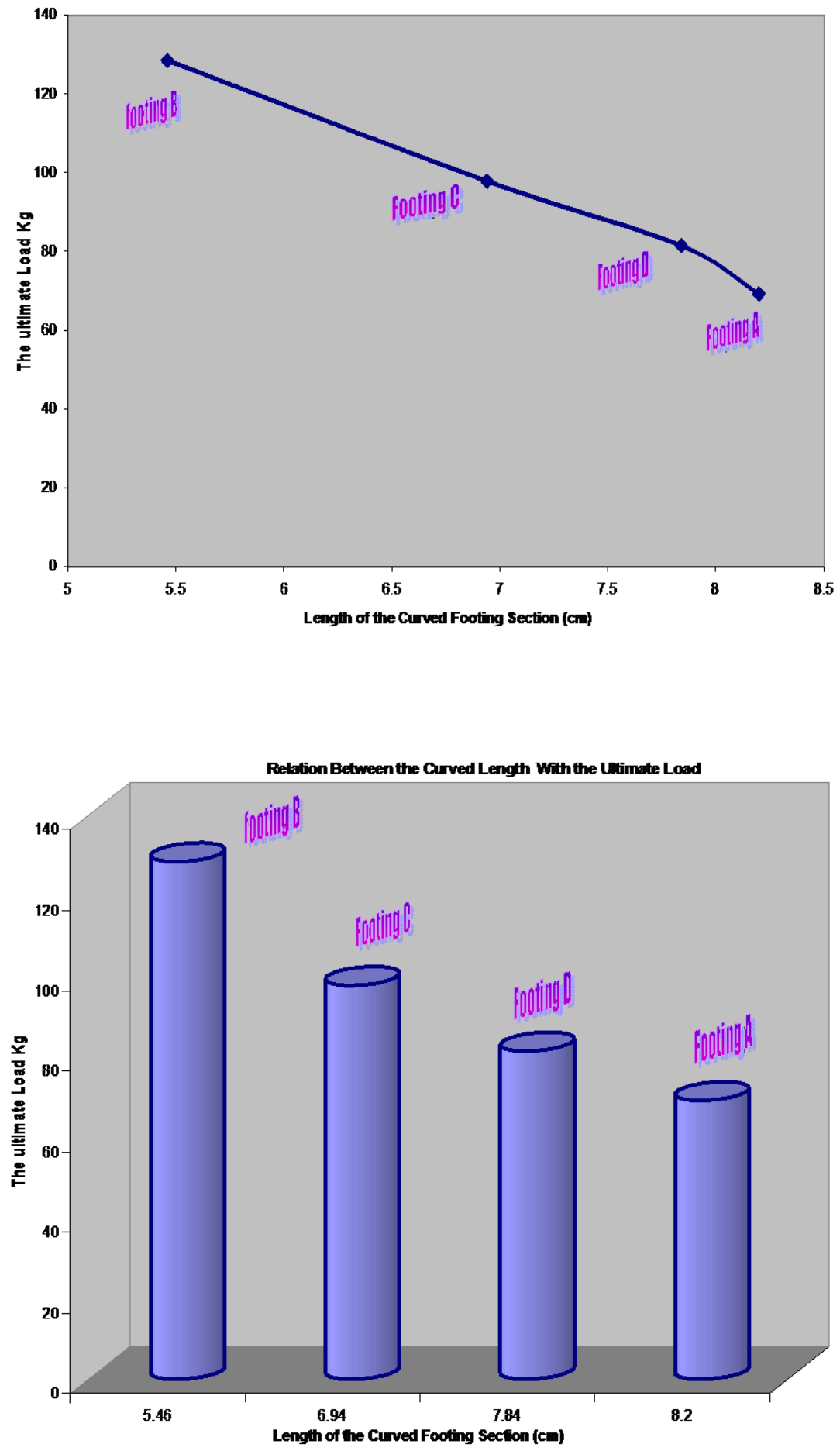

Fig ( 10 ) Length of the curved area with the ultimate load 
Relation Between the Section Curved Depth With the Ultimate Load

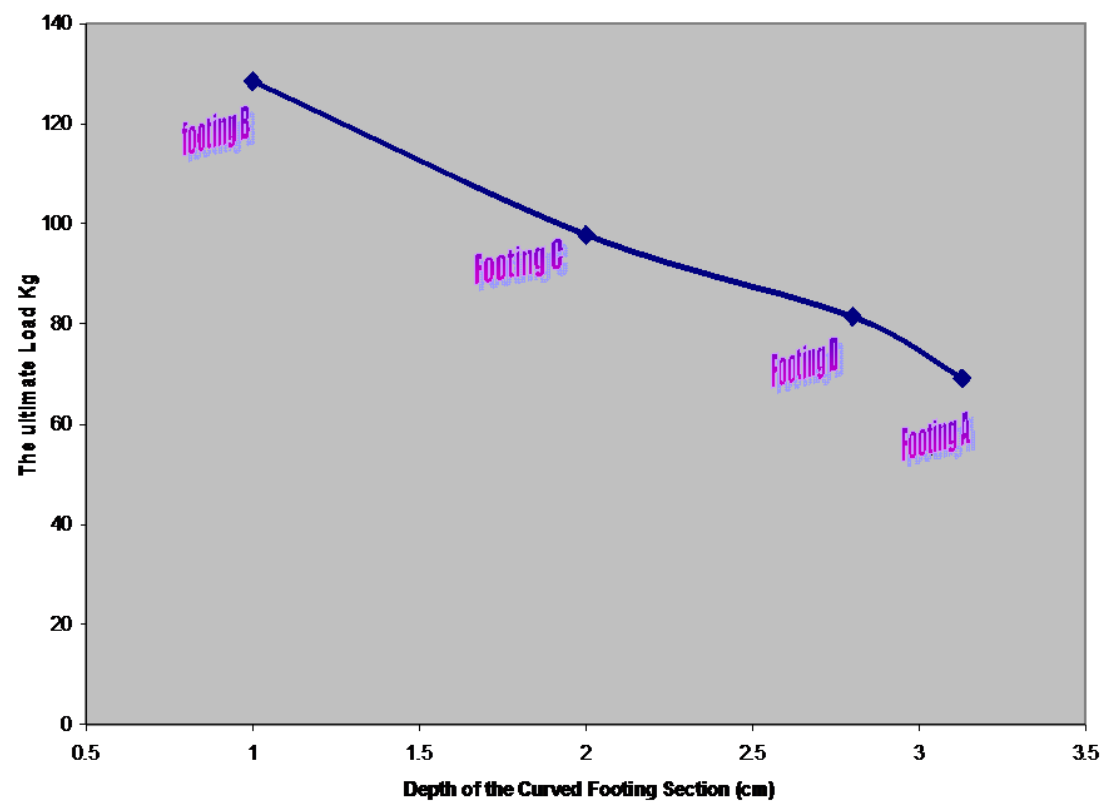

UItimate load with the curved depth

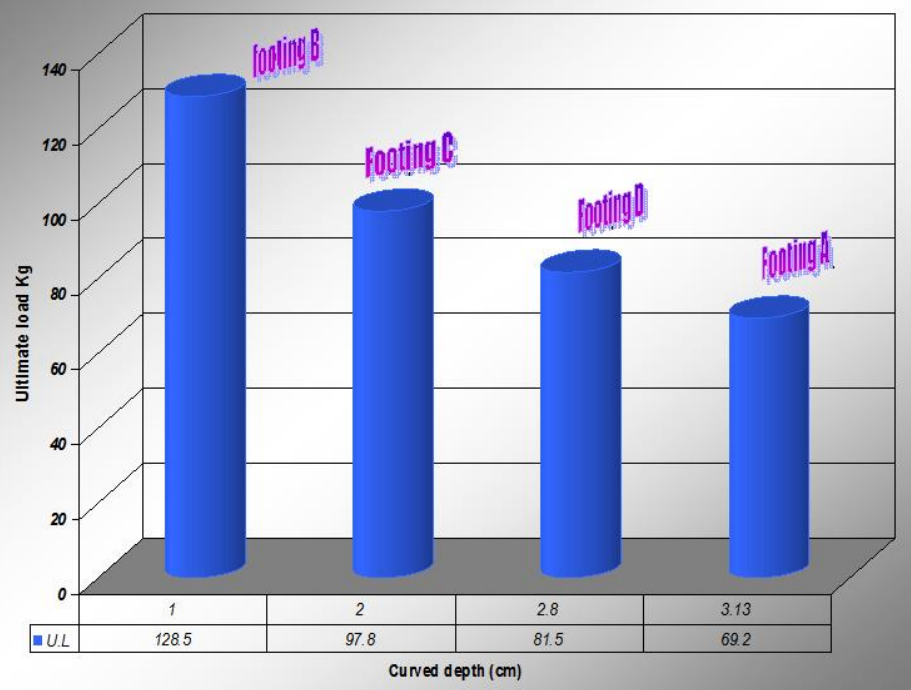

Fig ( 11 ) Depth of the curved area with the ultimate load 


\section{REFERENCES}

[1] Al-Aghbari, M. Y. S. (1999), "Bearing capacity of shallow strip foundation with structural skirts resting on dense sand", Ph.D. Thesis, University of Strathclyde, Glasgow, UK.

[2] Bransby, M. F. and Randolph, M. F. (1998), "Combined loading of skirted foundation", Geotechnique, 48(5), 637-655.

[3] Hansen, J. B. (1970), "A revised and extended formula for bearing capacity" Bulletin No.28, Danish Geotechnical Institute, Copenhagen, pp. 5-11.

[4] Hu, Y., Randolph, M. F. and Watson, P. G. (1999), "Bearing response of skirted foundation on non-homogeneous soil", Journal of Geotechnical and Geoenviromental Engineering, ASCE,125(11), 924-935.

[5] Meyerhof, G. G. (1963), "Some recent research on the bearing capacity of foundations", Can.Geotech. J., 1, 16-26.

[6] Reissner, H. (1924) Zum Erddruckproblem "Concerning the earth-pressure problem", Proc.1st Int. Congress of Applied Mechanics, Delft, pp. 295-311.

[7] Semih,H S. Tezcan, Ali Keceli, and Zuhal Ozdemir" Allowable bearing capacity of shallow foundations based on shear wave velocity" Geotechnical and Geological Engineering (2006) 24: 203-218_ Springer 2006

[8] Terzaghi, K. (1943). "Theoretical Soil Mechanics", John Wiley \& Sons, New York.

[9] Vesic, A. S. (1973), "Analysis of ultimate loads of shallow foundations" J. of SMFED, ASCE, 99 (SM1), 45-73.

\section{تأثير شكل سطح التلامس بين الأساس والتربة علي قدرة تحمل الأسناس الشريطي علي الرمل}

قدرة تحمل التربة تحت الأساس الثريطي درست منذ زمن بواسطة ترزاجي وغيره ـ. وهناك دراسات أخري

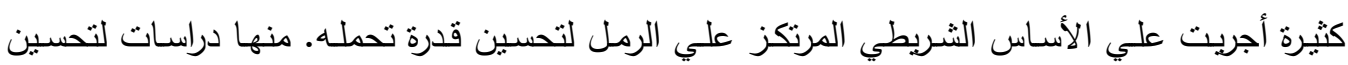

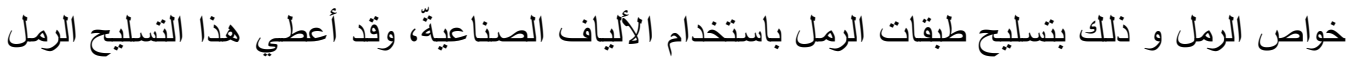

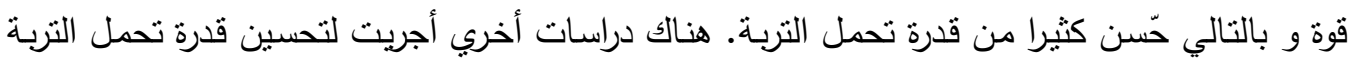

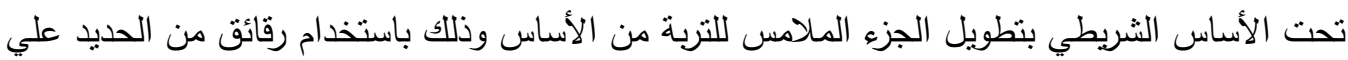

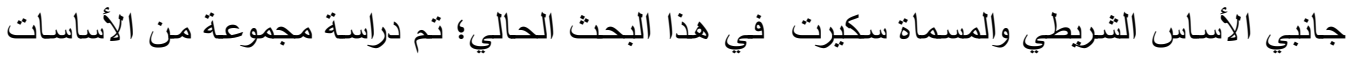

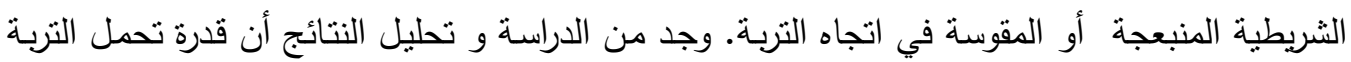

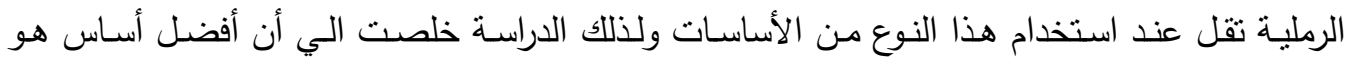

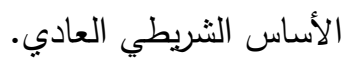

